\title{
DELIMITING THE SOCIAL BOUNDARIES OF COMPETITION LAW IN ASEAN: A COMMON APPROACH?
}

\author{
Dr. Haniff Ahamat ${ }^{1}$ \\ Dr. Nasarudin Abdul Rahman ${ }^{2}$
}

\begin{abstract}
This paper examines the interface between the economic and social elements of competition law in ASEAN. Generally, the aim of competition law should be to protect the process of competition, promote market efficiencies and enhance consumer welfare in the countries. Nevertheless there is a concern arising from such interface. Competition law strives to ensure competition and economic efficiency but market structure and behavior which harm competition or lead to inefficiency may have positive impact on the society. Along these lines, this paper looks into the social applications of competition legislation of Thailand, Indonesia, Singapore and Malaysia. Variations between different ASEAN
\end{abstract}

PhD (Essex, United Kingdom), LL.M (UKM, Malaysia), LL.B (Hons) (IIUM, Malaysia), Advocate and Solicitor (Malaya) (Non-Practicing), Assistant Professor of Law, Ahmad Ibrahim Kulliyyah of Laws, International Islamic University Malaysia. Email: ahaniff@iium.edu.my.

$\mathrm{PhD}$ (Macquarie, Australia), Advocate and Solicitor (Malaya) (NonPracticing), Assistant Professor of Law, Ahmad Ibrahim Kulliyyah of Laws, International Islamic University Malaysia, Email: nasarudin@ iium.edu.my. 
Members are expected to influence any discussions on this issue but social objectives of competition law, and social exclusions are among others the tools used to further social goals in the laws of the ASEAN Members that have been analysed. To address the possibility of political and special interest capturing such social interpretations of competition law, this paper proposes a model that requires increasing reliance on economic analysis and the use of proportionality principle to minimise subjectivity.

Keywords: competition law, competition policy, economic regulation, social welfare, economic justice

\title{
MENGHADKAN SEMPADAN SOSIAL DALAM UNDANG-UNDANG PERSAINGAN DI ASEAN: SATU PENDEKATAN YANG BIASA?
}

\begin{abstract}
ABSTRAK
Kertas kerja inimemeriksa sempadan yang membahagikan unsur-unsur ekonomi dan social dalam undang-undang persaingan di ASEAN. Secara umumnya, tujuan undangundang persaingan adalah untuk melindungi proses persaingan, menggalakkan lagi kecekapan pasaran dan meningkatkan kebajikan pengguna di negara-negara tersebut. Namun begitu, terdapat kebimbangan yang timbul daripada sempadan tersebut. Undang-undang persaingan adalah suatu usaha untuk memastikan persaingan dan kecekapan ekonomi tetapi struktur dan tingkah laku pasaran yang memudaratkan persaingan atau membawa kepada ketidakcekapan mungkin mempunyai kesan yang positif kepada masyarakat. Selari dengannya, kertas kerja ini melihat kepada aplikasi sosial keatas undang-undang persaingan di Thailand, Indonesia, Singapura dan Malaysia. Variasi diantara
\end{abstract}


Negara anggota ASEAN yang berbeza dijangka akan mempengaruhi mana-mana perbincangan mengenai isu ini tetapi tidak kepada objektif-objektif social undangundang persaingan, dan pengecualian social ini menjadi antara alat yang digunakan untuk meningkatkan matlamat sosial dalam undang-undang negara anggota ASEAN yang telah dianalisis. Untuk menangani kemungkinan kepentingan politik dan kepentingan khusus dari penafsiran social keatas undang-undang persaingan tersebut, kertas ini mencadangkan suatu model yang memerlukan peningkatan pergantungan terhadap analisis ekonomi dan penggunaan prinsip pembahagian setara bagi mengurangkan subjektiviti dalam penafsiran.

Kata Kunci: undang-undang persaingan, polisi persaingan, peraturan ekonomi, kebajikan sosial, keadilan ekonomi

\section{INTRODUCTION}

Competition law is one of the key elements in the establishment of the Association of South East Asian Nations Economic Community [hereinafter AEC]. As a precursor to the establishment of the AEC in 2015, all Member States of ASEAN [hereinafter AMSs] are required to introduce competition law in their national legal systems. As of now, Thailand, Indonesia, Vietnam, Singapore and Malaysia have put in place competition legislation enforced by the competition regulatory body of each respective country. Within the general conceptual framework, the aim of competition law should be to protect the process of competition, promote market efficiencies and enhance consumer welfare in the countries. Nevertheless there are concerns arising from the interface between the economic and social elements of competition policy considerations and framework. Competition law strives to ensure competition and economic efficiency but market structure and behaviour which harms competition or lead to inefficiency may have positive impact on the society. Competition law may exclude such situation or activity from the scope of the law or from liability provided by the law. On this note, this paper seeks to examine the extent of 
social applications of competition legislation of Thailand, Indonesia, Singapore and more importantly, Malaysia.

This paper begins with an evaluation of the objectives of competition law with the view of elucidating the social parameters of the law. This is followed by a discussion on the practice of the selected AMSs in including social considerations within the realm of competition regulation. The discussion centres around the culmination of social objectives of the competition laws of those AMSs, the recognition and implementation of social exclusions and exemptions in such laws, and the consideration of social factors in merger decisions.

Before the paper concludes, some observations will be made on the possibility of formulating common denominators for social considerations in ASEAN competition laws

\section{OBJECTIVES OF COMPETITION LAW}

Competition is a process of rivalry among firms in the market. Competition improves market efficiency by guaranteeing efficient allocation of resources in the society in which the production of goods and provision of services are undertaken at the minimum cost (static efficiency). ${ }^{1}$ Competition also brings about dynamic efficiency in the sense that the process of competition encourages producers to innovate to produce products of high quality with minimum prices, thus leading to technological progress. However, without a legal framework to protect the process of competition, the benefits arising from the competition could be reduced by anti-competitive conduct that restricts, prevents and distorts competition.

Competition law is an important instrument to provide rules of the game for firms to compete in the market on a level playing field. Therefore, it is widely accepted that the main purpose of competition law relates to the economic goal, i.e. to protect the process of competition expressed in term of economic efficiency to

$1 \quad$ F.Kronthaler, J. Stephan and F. Emmert, “Analysis of Statements Made in Favour of and against the Adoption of Competition Law in Developing and Transition Economies," www.cpftr.org/cpftr/ deliverables/Deliverable6.pdf, No. 5(2005) (last visited July 3, 2013). 
ensure that resources are allocated in an efficient manner. ${ }^{2}$ The increased efficiency and innovation contribute to overall economic growth and development in a particular country. Therefore, the economic efficiency objective of competition law is not the goal in itself but rather a means to achieve a higher end i.e., to foster the overall economic performance through the realisation of both static and dynamic efficiencies.

It has been raised from time to time whether competition law should promote non-economic objectives. In other words, should non-economic objectives or non-efficiency related goals be pursued in the name of competition law? Non-economic goals may take the form of social objectives or other public interest objectives. The notion of public interest may have wider interpretation to include social policy and goals. In the US, economists and lawyers of the Chicago school argued that competition policy should not concern itself with non-efficiency-related goals such as income distribution. Instead, this goal should be pursued through other public policies. The Chicago school 'considered efficiency gains as politically neutral, but regarded wealth transfers as politicized'. ${ }^{3}$

However, there is no 'one-size-fits-all' design for competition law. What might be considered an optimal policy for one country might not be for another. Implementing competition policy depends on the local context in which it is going to develop. For example, in some developing countries, in which the market has long been monopolised and concentrated, implementing competition policy is not about promoting and protecting the competition process. In the case of Chinese competition law for example, it was argued that at the early stage the aim of competition policy should focus on the creation of a competitive market, rather than maintaining an existing competitive market as found in developed economies. ${ }^{4}$ Consequently,

$2 \quad$ Hua Su, "Competition Policy in a Transition Economy: The Case of China," Competition Law and Policy in a Transitional China: Transplantation and Localization, (PhD Thesis, University of London, 2008): 262, citing Bing Song, 31 Stan. J. Int'l L. (1995): 387.

3 K.J. Cseres, "The Controversies of the Consumer Welfare Standard," The Competition Law Review, No. 3(2) (2007): 125.

$4 \quad$ Hua Su, supra note 4, at 262, citing Bing Song, id., at 394. 
one of the objectives of the Chinese Anti-Monopoly Law is to promote the healthy development of the socialist market economy. ${ }^{5}$

The main crux of competition law is to prevent anticompetitive behaviour such as cartel, monopolisation and abuse of dominant or monopolistic position, and mergers and acquisitions that lessen competition. The legal provisions of competition law are themselves consonant with the non-economic or social objectives such as promoting consumer interest, equity and wealth redistribution and the interest of small and medium enterprise [hereinafter SME]. Competition law may pursue non-efficiency related goals without sacrificing the efficiency goals. The law prohibits anti-competitive behaviour such as cartel and abuse of monopolistic position, but it also prevents price restraints, excessive price increase, market foreclosure and concentration of wealth. In this situation, while pursuing economic efficiency, the law will also indirectly benefit consumers and lower income groups. Competition law does not prevent a company from being dominant achieved through economies of scale and scope, but rather prevent the dominant firm from abusing its dominant position. Since the law against abuse of dominant position is targeting a firm with relatively high market share, competition law in this case will indirectly promote and protect the interest of the SMEs. In this case, it cannot be said that the economic and non-economic objectives of the competition is reciprocally incompatible but rather mutually enforced.

While the social benefits may be realised naturally or indirectly from the protection of the process of competition and from the promotion of economic efficiency objective, some countries have explicitly incorporated certain social activities as the objectives or one of the objectives of their competition law along with other economic goals. Some competition law systems take into consideration sociopolitical objectives when exempting and excluding certain anticompetitive activities which may otherwise contravene the spirit of competition law. The inclusion of express social objectives in the competition law helps a country to gain political acceptance on promarket reforms. For example, the objective of the South African competition law is the promotion of broader social goals, such as increasing the spread of ownership, especially among 'historically

$5 \quad$ Article 1, Anti-Monopoly Law 2007 (China). 
disadvantaged persons'. ${ }^{6}$ The design of competition law in the case of South Africa is to resolve historical issues such as the apartheid policy, which has led to imbalance in ownership and control of corporate wealth within the domestic economy. ${ }^{7}$ It has been acknowledged that incorporating other objectives attracted greater support to establishing a competition policy regime in South Africa. ${ }^{8}$

Thus, each country has a different political and social background as well as different levels of economic development. Different competition law systems address different concerns. Many competition law systems have in place the exemption regime which authorises otherwise anti-competitive conduct on the pretext to promote social or public interest objectives. For example, the Malaysian competition law explicitly releases an anti-competitive agreement if parties to the agreement can prove that the agreement produces social benefits ${ }^{9}$ (this will be further discussed below). The limits on competition are necessary in order to accomplish more important social policies such as affirmative action. This is important to avoid political turmoils and social repercussions. Political stability and social harmony are important ingredients for economic growth. In other jurisdictions such as the EU, the social goal or public interest policy is taken into consideration rather implicitly than explicitly. In Metro $v$ Commission, ${ }^{10}$ the European Court of Justice [hereinafter ECJ] considered that employment was a relevant factor under the first condition in Article 81(3), saying that the agreement under consideration was 'a stabilizing factor with regard to the provision of employment, since it improves the general conditions of production, especially when market conditions are unfavourable'. In Conseil Européen de la Construction d'Appareils Domestiques (CECED), ${ }^{11}$ the Commission took into consideration 'collective environmental

\footnotetext{
$6 \quad$ Section 2(f), Competition Act 1998 (South Africa).

$7 \quad I d$., at the Preamble.

8 An OECD Peer Review, Competition Law and Policy in South Africa, (2003): 18.

$9 \quad$ Section 5, Competition Act 2010 (Malaysia).

10 Case of C-26/76, Metro SB-Grossmarkte GmbH v Commission [1977] ECR 1875, 1916, Para 43.

11 Commission Decision of 2000/475/EC Relating to a Proceeding under Article 85 (1) of the EEC Treaty (IV.F.1/36.718. CECED) 2000 OJ (L 187/47), Para 55.
} 
benefits'. In Métropole Télévision SA v Commission, ${ }^{12}$ the Court of First Instance [hereinafter CFI] said 'in the context of an overall assessment, the Commission is entitled to base itself on considerations connected with the pursuit of the public interest to grant exemption under Article 85(3)' (emphasis added).

While using competition laws to promote social objectives (either through explicit objective (s) or through the exemption mechanism) may generate public support for the introduction and implementation of these laws, the difficulty of enforcing multiple objectives cannot be underestimated as taking into account multiple objectives when applying competition law may result in conflicts and inconsistent decisions. ${ }^{13}$ In addition, often it is unclear as to what kind of social policies that should be taken into consideration and the manner in which multiple objectives should be pursued i.e. whether they enjoy equal rank vis-à-vis economic goals or merely as a secondary consideration. ${ }^{14}$ These uncertainties and associated unpredictability will undoubtedly undermine the effectiveness of competition law enforcement. For example, a specific goal to promote SMEs in competition law may conflict with the objective of achieving economic efficiency and may end up protecting certain competitors rather than protecting the competition process. The non-efficiency goals can be associated with social concepts such as public interest, fairness and equity but these concepts may be ill-defined and also may be subject to different interpretations. This leads to contestations. The social objectives of competition law might be used to serve political interests, which is not conducive to maintaining a competitive environment.

The question now is can there be any possibility of reconciling between the economic efficiency goals and social goals of competition law?

12 Joined Cases of T-528/93, 542/93, 543/93 and 546/93, Métropoletélévision SA and Others v Commission [1996] ECR II649, Paragraph 118.

13 OECDandWorldBank, "Chapter 1:Objectives ofCompetitionPolicy", A Framework for the Design and Implementation of Competition Law and Policy, http://www.oecd.org/dataoecd/10/9/27122227.pdf, No. 4.

$14 \quad$ Constanze Semmelmann, "The Future Role of the Non-Competition Goals in the Interpretation of the Article 81 EC", Global Antitrust Review, No. 1(2008): 28. 
The economic efficiency model is based on the assumption that all men are rational (selfish) beings who only maximise their utility and if goods are allocated between consumers so that it would not be possible by any reallocation to make people better off without making anybody worse off, the situation will be Pareto-efficient and economic efficiency can be achieved. ${ }^{15}$ While maximisation of gains by the winner will increase welfare, there are valid concerns about the welfare of the loser. Economic efficiency will be increased if the magnitude of gains exceeds the magnitude of losses, ${ }^{16}$ but the loser still makes losses. Non-welfare arguments will quickly point to "payment" compensating the losers ${ }^{17}$ and this is very much linked to the use of taxation, subsidies and other policies to effectuate redistribution. But the answer to the problem could be provided by welfare economics itself.

The Pareto-efficiency was improved by Kaldor-Hicks efficiency which holds that an outcome is efficient if those that are made better off can potentially compensate those that were made worse off. ${ }^{18}$ The winners should be able to compensate the losers, not by making payment but by making it even between their gains and the losses of the losers. ${ }^{19}$ A producer can offer consumers a price that is below what they are willing to pay (this gives rise to a phenomenon known as consumer surplus) ${ }^{20}$ and the producer welfare can still be enhanced if it could produce the highest output levels at the lowest costs (producer surplus) ${ }^{21}$ and the producer surplus is further used to produce innovative products and services.

Nevertheless it is possible that producer surplus is concentrated in only one community or social group or that a systemic deficiency prevents the losers in the market from being

$15 \quad$ Kent Greenawalt, Law and Objectivity (New York: Oxford University Press, 1992), 170-174.

16 Ioannis Lianos, "Some Reflections on the Question of Goals of EU Competition Law", UCL Centre for Law, Economics and Society Working Paper Series 3/2013, No.3 (2013): 5, http://www.ucl.ac.uk/ cles/research-paper-series/research-papers/cles-3-2013 (last visited Nov. 22, 2013).

$17 \quad$ Id.

$18 \quad I d$.

$19 \quad I d$. , at 7.

20 The Efficiency created here refers to Allocative Efficiency.

21 The Efficiency created here refers to Productive Efficiency. 
compensated. Thus Amartya Sen argues that welfare should not only be measured in terms of utility-based Pareto-optimality so that there is more than economic efficiency (i.e. there should be social efficiency as well) for the welfare of a society to be enhanced. ${ }^{22} \mathrm{He}$ argues that it is possible to make 'cogent aggregative judgments about the society' (social welfare judgments) which take into consideration the distribution of utilities between persons. ${ }^{23}$ This is most apparent when a person is affected by 'persistent deprivation' such as when he lives in poverty or works under exploitative economic arrangements. ${ }^{24}$ In such cases, the rules determining welfare will differ in their acceptance of equity and efficiency so that factors such as inequality, poverty, distribution-adjusted national income and environmental evaluation will be taken into account. ${ }^{25}$

In contextualising Sen's criticisms to the conflicting objectives of competition law, economic efficiency is seen as creating situations which differ between different individuals and groups of individuals. Economic efficiency is usually linked to situations where goods or services are optimally produced at the minimum cost allowing the fruits of production to be available to consumers in the best form but at the lowest possible price. However these situations may also require workers to work more hours but with lower wages, forests to be cleared for agricultural and industrial activities, natural resources to be exhausted, inefficient factories to close down creating unemployment etc. Sen's argument that there should be social efficiency may mean that wealth will not be the sole indicator of well-being.

As a result we can see that in some countries public interest becomes the main justification for excluding the implementation of the economic efficiency objectives of their competition law. Public interest as a political concept, is defined by Laswell who associates it with the term 'common interest' which in turn refers to the inclusive social consequences of an activity ascertained by stated procedures of inquiry and the consequences are compatible with the goal of human dignity. Components of values which are determinant of human

22 Sen A, On Ethics and Economics, (Oxford and New York: Basil Backwell, 1987), 31-41.

23 Amartya Sen, "The Possibility of Social Choice", The American Economic Review, 89(3) (1999): 349.

$24 \quad I d$., at 358.

$25 \quad I d$., at 357. 
dignity are wealth, ${ }^{26}$ well-being, ${ }^{27}$ affection, ${ }^{28}$ skill,,${ }^{29}$ rectitude, ${ }^{30}$ respect, ${ }^{31}$ enlightenment ${ }^{32}$ and power ${ }^{33}$ but interactions between these values are both complementary and competitive depending on which society the individual lives in. ${ }^{34}$

Public interest emerges if the 'common interest' is sufficiently great to warrant the application of the public interest concept through inclusive coercive and non-coercive procedures..$^{35}$ Coercive procedure is reflected in the inducement to comply with a particular norm through sanctions while non-coercive procedure refers to the inducement through choices. In contrast, the common interest may be a private interest. ${ }^{36}$ The important factor that distinguishes between the public interest and a private interest is the inclusiveness or exclusiveness of the criteria of the interest and the procedures with which results that are in harmony with the criteria can be best achieved. ${ }^{37}$ The more inclusive the nature of the interest (the effects of an activity) and the procedures that allow concrete application of the interest, the easier they can be considered as public interest.

At the same time, public interest must become part of the corpus of competition law in order for it to be effectively gauged of its interaction with the economic efficiency objective. The layering or ordering of those factors that form the common interest will be a challenge. It is possible that different people or communities may view the importance of those factors differently. More importantly, not all countries incorporate public interest as the main trajectory for

$26 \quad$ The Value of Wealth refers to Wealth and Income.

27 The Value of Well-being refers to Mental and Physical Comfort and Safety.

28 The Value of Affection refers to Family and Friends; attachments to larger groups. The Value of Skill refers to Excellence in the Arts, Crafts, Professions. The Value of Rectitude refers to Worship and Sense of Responsibility. The Value of Respect refers to Recognition and Social Standing. The Value of Enlightenment refers to Information; Interpretation of Past, Future and Present. The Value of Power refers to Government and Legal Relations. Procedure in The Public Interest, (Friedrich, C.J. (ed.), 1962), 57. Id., 64.

Id.

Id. 
incorporating social considerations. As said, the problem with social goals of competition law is that they are ill-defined thus leading to uncertainties and unpredictability. The reliance on such goals may also lead to political and special interest captures.

Thus it is possible in theory to reconcile the social and economic objectives of competition law but it will be a difficult task to find ways to legally operationalise the reconcilable values and norms underlying those objectives. It will be difficult for governments to choose between populist policies that provide subsidies and social goods to citizens and the more economically sound policies which are based on economic efficiency. Fierce competition among States and the lure to reducing the cost of regulation ${ }^{38}$ may see the efficiency objective possibly trumping the non-efficiency objectives including the social objectives of competition law. But whether this occurs in ASEAN will require an analysis of how regulation of competition in ASEAN Member States allows the incorporation of social considerations into the respective competition legislation there.

\section{COMPETITION REGULATION IN ASEAN AND THE AVENUES TO INCORPORATE SOCIAL CONSIDERATIONS}

At the time of writing this article, only 5 ASEAN Member States (AMSs) have competition legislation in their legal systems namely Malaysia, Indonesia, Thailand, Singapore and Vietnam. There is no regional legal and institutional framework governing competition regulation in ASEAN, meaning that there is no regional competition code and no regional competition regulatory body in the region. All the five AMSs have adopted competition legislation with different substantive, procedural and institutional standards.

The lack of consistency between the competition laws applied in the AMSs is due to the vast differences among the AMSs in terms of political and legal systems and levels of economic and social development (for the purpose of this paper, 4 AMSs have been selected

$38 \quad$ For more discussions on de-regulation and privatization, see Robert Baldwin et. al., Understanding Regulation: Theory, Strategy and Practice (Oxford University Press, 2012). 
for comparison, Malaysia, Indonesia and Singapore thus the Competition Act 2010 (Malaysia) [hereinafter CA 2010], the Competition Act 2004 (Singapore) [hereinafter CA 2004], the Trade Competition Act 1999 (Thailand) [hereinafter TCA 1999] and Law No. 5 of 1999 (Indonesia) will be analysed). Focusing on the families of legal system which the selected AMSs belong to, the Malaysian and Singapore differ from Indonesia and Thailand in the sense that the legal systems of Malaysia and Singapore are based on common law while those of Thailand and Indonesia are based on civil law or at least reflect a hybrid system. That is from a macro perspective. From a micro perspective, the competition legislation itself may be modeled after the law of different countries. Malaysia and Singapore's competition law statutes (CA 2010 and CA 2004) are modeled after EU competition law with modifications to suit local circumstances. Indonesian and Thailand competition laws (Law No. 5 of 1999 and TCA 1999) however have a hybrid character.

Thus all the laws are expected to have different objectives, and substantive, procedural and institutional provisions. Different objective and substantive provisions may result in inconsistency in the manner in which the social boundaries of competition regulation are delimited. This will be further discussed below.

The variance is not only due to the legal provisions and principles adopted in the selected AMSs. All AMSs in particular, Indonesia, Thailand, Malaysia and Singapore, have different political, economic and social environments making it hard for uniform rules to be applied through the ASEAN region. Singapore has a population of 5 million, Malaysia has a 30 million population, and Thailand has a population of 65 million while Indonesia has a 270 million population. The levels of economic development of these countries also differ. Singapore's economy is very advanced concentrating on high-tech industries and services with big and highly-competitive players predominant in its market. Malaysia and Thailand on the other hand, is experiencing a transition from labour intensive to high-tech industries with broad participation of foreign and local (but government-linked, for Malaysia) big players as well as SMEs. Indonesia's economy is still predominantly agricultural with big participation of SMEs in the economy. 


\section{Social Objectives of Competition Law in Malaysia, Indonesia, Thailand and Singapore}

As said, the objectives of the competition legislation in Malaysia, Indonesia, Thailand and Singapore vary and the variations reflect the different political, legal, economic and social environment prevailing in these countries.

The objectives of Malaysian competition law are found in the preamble of the CA 2010 which stipulates that its main objective is to protect the process of rivalry among firms based on the belief that effective competition will result in economic efficiency and innovation. The CA 2010 also has a secondary objective that is to promote consumer interest based on the belief that the consumer may benefit indirectly from the protection of competition by enjoying lower price, various choices and product and services of good quality. Both objectives are tied to a wider objective that is the objective of promoting economic development. Here, it is important to note that while protection of the competition process is pivotal, it is "tied" to the objective of ensuring economic development. Competition and economic efficiency may not be a goal in and of themselves but a means to achieve a higher end i.e., economic development. There may be conflicts between economic efficiency considerations and economic development considerations which will require a special formula to be adopted by the Malaysian competition authority to determine which objectives prevail.

In Singapore, the main competition legislation i.e. the CA 2004 does not mention specific objectives in its preamble but the Competition Commission of Singapore [hereinafter CCS], in its guidelines states that the aim of competition law is to ensure that markets are competitive by protecting the competitive process. ${ }^{39}$ The competitive process is further linked to consumer interests where the guidelines highlight the need to empower customers to exercise choice. More detailed explanations of such an aim of competition law reflects the achievement of all the three types of efficiency by competition law - allocative efficiency, productive efficiency and dynamic efficiency.

39 Competition Commission of Singapore, CCS Competition Philosophy,http://www.ccs.gov.sg/content/ccs/en/About-CCS/ What-We-Do/CCS-Competition-Philosophy.html (last visited Nov. 23, 2013). 
While the Malaysian and Singapore's competition law statutes make direct reference to protecting the process of competition, the competition law statutes of Indonesia and Thailand look a bit different in terms of the objectives of the law.

The objectives of Thailand competition law are not explicitly mentioned in the TCA 1999. However in a document submitted by Thailand to the Organization for Economic Cooperation and Development, the objective of the law is to promote fair and free trade with competitive environment. ${ }^{40}$ Free trade and competitive environment can be understood as pursuing economic goals expressed in the term of economic efficiency whereas the word 'fair competition' may promote wider objectives such as social goals and well-being of economic actors. The word 'fair' is ill-defined and subject to value judgment and political influences.It may be used to protect small and medium competitors rather than the process of competition. For example, the Thai Competition Commission [hereinafter TCC] has resorted to unfair trade practice legislation against exclusive dealings in the motorcycle market instead of abuse of dominant position found in competition law. This selective case gives power to the Commission to hold large foreign companies liable in exclusive dealings without having to prove the market dominance of the alleged business. ${ }^{41}$

The Indonesian competition law statute (Law No 5/1999) pursues multiple and even conflicting goals. The preamble of the law states that it draws upon the consideration of the following:

1. realisation of people's welfare

2. economic democracy (which explicitly mentions economic growth as one of the aims of the law)

3. the requirement of healthy competition for business conduct, getting rid of concentration of economic power

Apart from the preamble, Article 3 of the Law No 5/1999 provides that the purposes of the law are to maintain public interest and promote national economic efficiency, create equal business

$40 \quad$ OECD, "Contribution from Thailand", OECD Global Forum on Competition, 26 September 2001, CCNM/GF/COMP/WD 8 (2001): 1 .

Deunden Nikomborirak, "Political Economy of Competition Law: The Case of Thailand, The Symposium on Competition Law and Policy in Developing Countries", Northwestern Journal of International Law and Business, No. 26(3) (2006): 605. 
opportunities to big corporations and SMEs, prevent monopolistic practices and/or unfair business competition and create efficiency in business activities.

The objectives of Indonesian competition law are loosely written to allow a variety of different interpretations. The Indonesian competition law pursues multiple objectives including both economic and non-economic goals. Since the Indonesian economy is dominated by small and medium enterprises, the promotion of social objectives such as creating equal business opportunities and fair competition help to gain political acceptance and to push the law through. While adopting multiple objectives is important and necessary to tailor the law with the local needs and condition, having multiple objectives may result in inconsistency and uncertainty. The law may be a floodgate to regulatory capture. The manner in which various objectives will be pursued is still unclear. For example, it is still uncertain whether economic goals should take precedence over non-economic or sociopolitical goals or in what circumstances non-economic goals are allowed to trump competition objectives. Any attempts to take into account multiple objectives 'may cause inconsistency outcomes because such an approach increases analytical complexity, reduces predictability and legal certainty, negatively affects the assessment of objectivity and fairness, and thus impacts the ability of competition law to achieve its economic objectives. ${ }^{42}$

Several articles in the Indonesian competition law such as articles 4,13,17 and 18 suggest that the objective is to limit the growth of large firms while protecting the market of smaller firms. The specification of maximum market shares for monopolies, monopsonies, oligopolies and oligopsonies that would trigger action by the Commission suggests that the objectives of the law are not, in fact, to ensure that all firms have equal rights to compete, but rather that it is to limit the growth or reduce the size of large firms, quite independently of whether they are engaged in anti-competitive business conduct. The law already presumes that certain market share will lead to anti-competitive effects, without the underlying economic analysis or proof that an anti-competitive outcome results.

42 Hua Su, Competition Law and Policy in a Transitional China: Transplantation and Localization, ( $\mathrm{PhD}$ Thesis, University of London, 2008), 74. 
This can be best illustrated in the case of Indomaret where the Indonesian Competition Commission i.e. Komite Pengawasan Perusahaan Usaha [hereinafter KPPU] decided to prevent a large supermarket from expanding into areas where small stores were predominant on the ground that it would upset the balance in the principle of economic democracy between the interests in healthy competition and public interest. ${ }^{43}$ The KPPU in a way had ordered the large supermarket to give way to small-scale retailers so that there would be balance in the competition between large-scale, mediumscale and small-scale players. ${ }^{44}$ The KPPU failed to identify any anticompetitive behaviours committed by Indomaret (i.e. protecting the market share of existing small traditional retailers against the expansion of the Indomaret chain). The KPPU appears to be more concerned with protecting existing competition than with protecting the public interest by affirming its support for the competitive process. ${ }^{45}$

At the same time, apart from the objectives of the law, it is important to look at two other dimensions of the law in order to sieve the social considerations underlying the competition laws of the four countries. They are the exclusions and exemptions provided by the laws.

\section{Social Exclusions and Exemptions}

It is common that competition legislation excludes and exempts certain types of commercial activities from its application. Exclusions and exemptions can be different depending on the system adopted by the competition law statute of a particular country. In countries like Malaysia and Singapore, exclusion and exemption are invoked by

$43 \quad$ See the decision of Indonesian Competition Commission (KPPU) in P.T. Indomarco Prismatama (2000), 03/KPPU-L-1/2000, 27, http:// www.kppu.go.id/docs/Putusan/putusan indomaret.pdf (last visited Nov. 23, 2013).

$44 \quad I d$. Also see Eleanor Fox, "We Protect Competition, You Protect Competitors", World Competition Law and Economic Review, 26(2) (2003): 149-166.

45 Thee KianWie, "Competition Policy in Indonesia and the New Anti-Monopoly and Fair Competition Law", Bulletin of Indonesian Economic Studies, 38(3) (2002): 331-42. 
parties in different stages of proceedings where the former revolves around the question whether the competition legislation applies to a particular activity while the latter is raised upon the belief that the activity is governed by the legislation and possibly caught by any of the prohibitions thereunder. Exemptions are normally used as both defence to infringement allegations and grounds for granting either individual and/or block exemptions by the relevant competition regulatory bodies.

\section{Malaysia}

In relation to Malaysia, the CA 2010 is only applicable to enterprises carrying out commercial activities. The CA 2010 excludes activity in the exercise of government authority, activity based on the principle of solidarity, and purchasing activity not for the purpose offering product and service to the market. The CA 2010 also excludes conduct or agreements which need to comply with the legislative requirements, collective bargaining in employment sector and enterprises entrusted with services of general economic interest [hereinafter SGEI]. Looking at the grounds for excluding the application of CA2010, there are several grounds which can form the social exclusions from the applicability of the law to the activity/conduct/agreement concerned:

1. Activity in the exercise of government authority

2. Activity based on the principle of solidarity

3. Conduct or agreements that need to comply with legislative requirements

4. Collective bargaining agreements and

5. SGEI conduct or agreements

It must be noted that grounds (1) and (3) relate more to public policy but the policy may incorporate socio-economic and social considerations.

Under the gist of "activity in the exercise of government authority" the CA 2010 protects the public authority in carrying out public interest activities on behalf of the state from the application of competition law. Normally, public interest activities are associated with the official or prerogative functions of the state. These activities are essential for the interests of citizens; for example, activities for 
safety and environmental protection, technical standardisations or R\&D activities. ${ }^{46}$

The CA 2010 also adopts the principle of solidarity as found in other developed jurisdictions such as the EU and UK. This principle protects entities that fulfil an exclusively social objective for example, entities that provide social security, pensions, health insurance or health care services. These services are provided as part of the prerogative of the State services or Services of General Interest (as opposed to the SGEI concept). The principle of solidarity has been described as: 'the redistribution of income between those who are better off and those who, in view of their resources and state of health, would be deprived of the necessary social cover ${ }^{37}$ or 'designed as a matter of priority to assist those who are in a state of need' ${ }^{48}$ In Christian Poucet $v$ Assurances Générales de France and Caisse Mutuelle Régionale du Languedoc-Roussillon" ${ }^{49}$, the ECJ decided that 'sickness funds, and the organizations involved in the management of the public social security system, fulfil an exclusively social function'.

The CA 2010 acknowledges the social role played by collective agreement in countervailing the bargaining power of firms vis-a-vis individual workers and preventing the exploitation of labour. ${ }^{50}$ This requires fixing wages in a way that may be inconsistent with the spirit of competition law. The application of the competition law in this area would undermine the role of collective agreement in

$46 \quad$ See Case C-364/92, SAT Fluggesell schaft v Eurocontrol [1994] ECR I-43, dealing with European an air traffic control organisation in charge of maintaining and improving air navigation safety; Case C-343/95, Diego Cali e FigliSrL v. SEPG, [1997] ECR I-1547, dealing with a private entity engaged in pollution monitoring at Genoa harbour; and Case C-30/87 Corinne Bodson v SA PompesFunèbres des RègionsLibèrèes, [1988] ECR 2479, dealing with local communes responsible for granting concessions for funeral services. France, [1993] ECR I-637, Para 10. Case 70/95, Sodemare v Regione Lombardia, [1998] ECR I-3395, Para 29.

Cases C-159/91 and C-160/91, Poucet et Pistre v Assurances Générales de France and Caisse Mutuelle Regionale du LanguedocRoussillon [1993] ECR I-637, Para 18. 
improving employment and work conditions, thus undermining the overall public interest goal.

The CA 2010 also excludes services of general economic interest (SGEI) from its application. The European Commission has stated that 'services of general economic interest' are services that 'public authorities consider need to be provided even where the market may not have sufficient incentives to do so'. ${ }^{51}$ Due to the natural monopolistic character of these industries, the government tends to grant or maintain special or exclusive rights in favour of that single operator or group of operators. The postal service is expected to be excluded from the ambit of the CA due to its SGEI nature, especially due to the presence of market failures, such as natural monopolies and the need to meet universal service obligations. Credit institutions may also be designed as SGEI to promote the interest of SMEs and other socio-economic objectives such as extending social housing loans to the public at large. In the case of postal service, basic nonapplication of competition law is necessary to preserve 'cross-subsidy' or to prevent competitors from selecting the most profitable parts of the postal service system, leaving the non-profit part such as universal service provision to the holder of the exclusive right.

Apart from exclusions, social considerations may find ways into the exemption process. An enterprise may apply for individual exemption under Section 6 of the CA 2010 and the Malaysian Competition Commission [hereinafter MyCC] may grant a block exemption covering certain agreements under Section 8 of the CA 2010. An anti-competitive agreement under sec 4 can be exempted from prohibition in Section 4 of the CA 2010 if it fulfills the criteria provided for in Section 5, namely that the agreement must produce efficiency, social and technological benefits, as well as the requirement of indispensability, proportionality and substantial elimination of competition. The mention of social benefits as a ground for exemptions indicates that social considerations enjoys equal rankingvis-à-vis economic goals and may trump economic efficiency considerations provided that the social benefits are proportionate to the harm to market competition.

51 See the EU Commission's Communication on Service of General Interest in Europecase, supra note 67, Para 14. 
However, the CA 2010 does not define what can be considered as social benefits that allow enterprises to enjoy the exemption relief. In addition, the manner in which the social objectives should be balanced against the effect of the agreement on competition (to see the proportionate effect)is still unclear, i.e. how much weight should be given to social considerations and to how far that the agreement is allowed to degrade the level of competition in the relevant market. The potential clash between promoting competition and the other social goals of competition law is best illustrated by the case of regulation governing legal professional services. Regulatory scheme governing the legal profession such as fixing of the scale of fees might be important to maintain sound professional standards, and to ensure the integrity of the profession is safeguarded in the interest of the public. However, the scale of fees system may result in anti-competitive practices that will injure consumers. The Solicitors Remuneration Order 2005 which fixes the fee for certain legal services may be used as a "legal sanction" by legal firms to collude to fix the price of a particular legal service. Therefore, it is highly likely that complicated trade-offs emerge between maintaining competition and promoting other social objectives.

\section{Singapore}

The Singapore competition law statute (CA 2004) has exclusion provisions as well. The following activities are excluded from the application of such law:

1. Service of General Economic Interest (SGEI) activities;

2. Activities necessary to comply with legal requirements or to avoid conflict with Singapore's international obligations;

3. Activities arising from exceptional or compelling reasons of public policy;

4. Conduct relating to the clearing and exchanging of articles undertaking by the Automated Clearing House or activity of the Singapore Clearing Houses Association in relation to its activities regarding Automated Clearing House;

5. Vertical agreements, i.e. arrangements between businesses at different levels of the production or distribution chain; 
6. Activities regulated under Postal Services Act, Public Transport Council Act, Rapid Transit Systems Act, Maritime and Port Authority of Singapore Act;

7. Sectors have been excluded based on public interest considerations such as national security, defence and other strategic interests or because existing sectoral competition frameworks are already in place;

8. Agreement exempted under block exemption;

9. Any agreement entered into or any conduct on the part of the Government; any statutory body; or any person acting on behalf of the Government or that statutory body, as the case may be, in relation to that activity, agreement or conduct unless prescribed by the Minister.

Compared to the Malaysian CA 2010, the grounds contained in the Singapore CA 2004 for excluding the application of the competition legislation are more specific but there is less room for manoeuver for those wanting social considerations to be included in a competition decision. Possibly such considerations can be argued under the headings of SGEI, public interest considerations, public policy, compliance with international obligations (but will depend whether the social considerations have culminated in international standards), special statutory regulations (particularly the Public Transport Council Act implementation of which involves services which may not be profitable but yet important to certain sectors of the society).

The Singapore competition law excludes certain agreements from the ambit of the law provided that it fulfills certain criteria. First, the agreements must have net economic benefit such as improving production or distribution, or promoting technical or economic progress. Second, the restrictions are absolutely necessary to achieving these benefits, and third the agreements do not substantially eliminate competition.

Unlike the Malaysian competition law, the Singapore competition law does not include social benefits a ground to exempt an agreement. The question is whether the non-economic goals have legitimate place in the Singapore exemption regime. Attempt to include social considerations can be illustrated in the case of the 
Singapore Medical Association. ${ }^{52}$ This case relates to the notification by the Singapore Medical Association [hereinafter SMA] Guidelines on Fees for Doctors in Private Practice in Singapore [hereinafter the GOF] which recommends a range of fees (i.e. consultation fees, medicine fees, prescription fees, medical report fees, surgical fees, and doctor's court appearance fees) for medical services and procedures. ${ }^{53}$ The social and public interest benefit was invoked in by the SMA to release the guidelines from the ambit of the Singapore competition law. It was claimed that since the degree of information asymmetries in the Singapore healthcare services is relative high, the GOF is important to protect the patient's interest 'by increasing transparency of healthcare costs, diminishing the information asymmetry between patients and medical practitioners, allowing patients to make an informed choice of medical practitioner, so that over-charging can be identified and curbed in the private sector' ${ }^{54}$ It was also submitted that the increase in price of private medical services may result in the consumption of the medical service falling below socially and economically optimal levels. ${ }^{55}$ However, the Singapore Competition Commission decided that the GOF did not meet the requirements of either improving production or distribution, or promoting technical or economic progress, of medical services in Singapore to in order to qualify for an exclusion from the application of Section 34 of CA 2004. ${ }^{56}$

52 Competition Commission of Singapore, Decision against the Singapore Medical Association in relation to its Guideline on Fees Pursuant to Section 44 of the Competition Act (Issued Decision, 18 August 2010), http://www.ccs.gov.sg/content/dam/ccs/PDFs/ Public_register_and_consultation/Public_register/Anticompetitive Agreements/SMA-SD $\% 20 \% 2818 \% 20 \mathrm{Aug} \% 202010 \% 29$.pdf24 (last visited July 3, 2013).

53 Competition Commission of Singapore, Singapore Medical Association's Notification on Guidelines on Fees (Notifying Date, 5 February 2009), http://www.ccs.gov.sg/content/ccs/en/PublicRegister-and-Consultation/Public-Register/Anti-competitiveAgreements.detail.singapore_medicalassociationguidelinesonfees. html (last visited July 3, 2013).

$54 \quad$ Supra note 55.

$55 \quad$ Id.

$56 \quad$ Section 34 of the Competition Act 2004 (Singapore) prohibits vertical or horizontal agreements which have the object or effect of preventing, distorting or restricting competition in Singapore. 
It is interesting to note here that social or public interest consideration may have legitimate place in enforcing the Singapore competition law. However, the social benefits may be taken into consideration if it can be translated into economic efficiency gains (such as improving production or distribution, or promoting technical or economic progress) and has pro-competitive effects such as curing market failure and resolving the issue of information asymmetries.

\section{Indonesia}

As regards Indonesia, the Law No. 5 of 1999 provides social exemptions in the provisions on general exemptions (Articles 50 and 51). The general exemptions highlight the influence on Indonesian competition law by diverse policy considerations such as protection of intellectual property rights, international trade and more importantly those considerations include protection of SMEs and also the consideration of national interest in the activities carried out by State-owned enterprises. ${ }^{57}$

On this basis, Article 50 excludes certain conduct or agreements from being regulated by Law No 5 of $1999^{58}$ but social considerations are likely to entail from agreements to implement applicable laws and regulations, agreements to promote and improve people's standard of life, activities of small-scale enterprises and activities of a cooperative serving its members.

In relation to agreements or conduct to implement applicable laws and regulations, an enterprise that is implementing a particular

57 A.F. Lubiset. al., Hukum Persaingan Usaha: Antara Teks dan Konteks, (Indonesia: Deutsche Gesellschaftfür Technische Zusammenarbeit (GTZ) GmbH, 2009), 219, online version http:/www.kppu.go.id/ docs/buku/buku_ajar.pdf (last visited Nov 22, 2013).

58 They are those regarding intellectual property rights, agreements related to franchise, agreements to implement applicable laws and regulations, agreement to set up certain technical standard, agreement on agency, agreement on research and development, agreement to promote and improve people's standard of life, ratified international agreement, export agreements, activities of small-scale enterprises and activities of a cooperative serving its members. 
order pursuant to a legislative requirement must be "instructed" or such power or authority is delegated by a law or regulation, or the enterprise itself was constituted or instructed by the State. This kind of exemption is needed to balance the inequitable economic strength of big corporations and SMEs such that the latter can be empowered to move up to the level playing field, as well as to ensure access to public goods which can only be effectively facilitated by the State will not be disrupted by economic considerations of private players. An example of such laws and regulations that are concerned with social exemptions is Law No 19 of 2003 on Nation Social Security System and Law No 19 of 2003 on State-Owned Enterprises which may indulge in anti-competitive conduct or agreement in the course of providing essential services to the wider public.

As said, agreements and conduct to promote and improve people's standards of life are also exempted under Law No 5 of 1999. The context of this exemption needs to be understood in order to establish its parameters. This type of agreements and conduct is common in an industry with a high level of collective participation, be it through combined efforts of business organisations or through decisions of trade associations. However the relevant venture is capital intensive but the fruits of the venture must be made available to the wider public. This of course refers to essential facilities such as the rail networks for the rail industry and distribution as well as transmission networks for the energy industry.

Finally, the social exemptions also cover agreements and conduct of the SMEs and cooperatives. Promotion of the interests and empowerment of SMEs as part of the wider notion of economic democracy has legislative mandate, in particular, following the success of the reformation movement in 1998. However, the main setbacks to the exclusion of SMEs from competition in Indonesia will be the lack of certainty in establishing the criteria for SMEs who can benefit from the exemptions and the difficulty of determining the limitations to the enjoyment of such benefits. The limitations are crucial for any discussion on possible "graduation" requirements that will cease the exemption given to an SME after certain circumstances have occured. As regards activities of cooperatives, their competition 
exemption very much depends on legislative authorisations ${ }^{59}$ but the rationales of exemption have some similarities with exemption and protection given to SMEs in terms of empowering and enhancing the capacity and resilience of such small players in competing against big players in the economy. The activities must come from and create outputs for the members of cooperatives while the exemptions will come hand in hand with direction from the Government to restrict entry into certain industries except for cooperatives with special consideration given to national economic interest, equal opportunities to do business and to work. ${ }^{60}$

Article 51 of the same law extends the exclusions/exemptions to monopoly or concentration of activities related to the production or marketing of goods or services affecting the livelihood of society at large and branches of production of a strategic nature for the state but it shall be stipulated in a law and shall be implemented by State-Owned Enterprises or institutions formed or appointed by the Government. The phrase livelihood of society at large refers to an activity that allocates goods or services derived from the State's natural resources to be used for the maximum enhancement of people's well-being (allocative), that distributes essential goods or services that are by nature difficult to be supplied by the market alone (distributive) and that stabilises the supply of goods or services that can be dispensed on the ground of public interest (stabilising). ${ }^{61}$ The second phrase that is production of strategic nature of the State refers to productive activities in the strategic fields that protect national defence and maintains law and order as well as those in the financial purview that ensures monetary stability and financial security and other public interest needs. However as mentioned above, in order to be exempted, the activities must be governed by legislation and implemented by or via the Government. If this is fulfilled, the exemption will allow monopoly and concentration activities to pursue social goals without any intervention from competition regulation.

In short, the Indonesian law exempts activities that enhance economic efficiency and protect intellectual property as well as activities that have social and public interest dimensions such as small

$59 \quad$ See Law No 70 of 1958 on Cooperatives which first prescribed the regulations for cooperatives, and the much recent Law No 25 of 1992 on Cooperatives.

$60 \quad$ Lubis, supra note 58, at 293.

$61 \quad I d ., 306-308$. 
scale activities and activities of cooperatives. The exemption regime will be enforced, keeping in view the Indonesian competition law objectives. Promoting competition and economic efficiency is not the only goals of the Indonesian competition law. The competition goal will have to be balanced against other broader objectives such as improving people's quality of life. A great deal of uncertainties and unnecessary subjectivities will develop from this system making it likely for the law to be used to protect inefficient competitors rather than competition itself.

\section{Thailand}

The applicability of the main Thai competition legislation i.e. TCA 1999 is subject to the exemptions enumerated in Section 4 of the Act. The provision states that the TCA 1999 shall not apply to the act of:

1. Central, provincial or local administration

2. State enterprises under the law of budgetary procedure

3. Farmers and cooperatives representing them

4. Businesses prescribed by Ministerial regulation which provides for exemption from the law.

Again social considerations may be pursued by the Thai competition authority when exempting the acts of government, public funded State enterprises and regulation-backed businesses from being subject to the prohibitions found in the TCA. But social character is more evident in the exemption given to farmers' activities. The question now is whether such exemptions are available to large scale farmers which play a very big role in the Thai economy. The Thai competition law limits the exemption in agriculture only to the extent of farmer's groups or cooperatives, which means the exemption will be limited to smallholding farmers. This allows them to be shielded from free market competition. This exemption however has not come about without any criticisms. Large-scale farmers had complained that the exemption regime is unfair as exemption is given to State-owned enterprises. ${ }^{62}$

62 S. Thanitcul, "Competition Law in Thailand: A Preliminary Analysis”, Wash. U. Glob. Stud. L. Rev, 1(2002): 175. 


\section{Social Considerations in Merger Decisions}

Not all AMSs have provisions on merger control in their competition legislation. Singapore and Indonesian competition laws have such provisions while Malaysian competition law does not. In examining the possibility of including social considerations in merger decisions, this paper looks into the consideration of social factors such as employment by the relevant competition regulatory bodies when deciding on anticompetitive mergers or to clear proposed mergers or acquisitions notified to them.

In Singapore there is no explicit mention of social factors as the required elements that have to be considered by the CCS in making a merger decision. However the CCS Guidelines on Merger Procedures 2012 allows merger parties to apply for exemption on public interest considerations if the CCS makes an unfavourable decision. The issue now is whether public interest considerations include social considerations like the consideration of the effect of a merger or acquisition on employment. Public interest is defined in Section 2 of CA 2004 as "national or public security, defence and such other considerations as the Minister may, by order published in the Gazette, prescribe." ${ }^{33}$ As of now, there is yet any gazetted definition of public interest considerations other than national or public security and defence, limiting such considerations to those explicitly mentioned in the CCS Guidelines.

In Indonesia, the Merger Control Regulations provide that the evaluation of anti-competitive mergers or acquisitions shall involve the analysis of the following factors: market concentration, entry barriers, possible anti-competitive behaviour, efficiency and/or bankruptcy. The assessment of the impact of a proposed merger on bankruptcy may require the consideration of the positive or negative effects of such merger on employment, for example the merger may be necessary to prevent the closing down of a business or the merger itself may contribute to such closure hence it must not be approved on the ground of preventing job losses. Therefore the inclusion of bankruptcy as a factor can facilitate the consideration of the social costs and benefits of the merger. At the same time the Regulations

63 Competition Commission of Singapore, CCS Guidelines on Merger Procedures 2012 (2012), Guideline 7.2. 
allow the Commission to analyse other factors but such analysis must be pursuant to a regulation of the Commission. These other factors may also include social factors but whether this is the case depends on the issuance of an order or regulation by the Commission.

\section{COMMON DENOMINATORS}

It is acknowledged that different countries adopt different competition law systems to suit their local conditions and needs. However, it is recommended that the fundamental objective of a competition law should be to protect the process of competition expressed in the form of economic efficiency gains thus, promoting the overall economic growth and development. ${ }^{64}$ Economic analysis should play a central role in the application of competition law. This is because economic analysis imparts a greater precision and predictability and thus, limits the discretion of the decision-makers and increases transparency. Increasing reliance on the economic analysis helps to harmonise different competition system in ASEAN. It is argued that:

It is widely acknowledged that the application of economic analysis imparts a greater degree of precision and predictability in the enforcement of competition policy. Economic tools can be used effectively to analyse non-economic concerns, such as the fairness or equity implications of enforcement decisions, or to systematically assess the effects of different business practices and market structures. ${ }^{65}$

Social objectives are best pursued through other stand-alone policies or legislation. Social considerations should be separately examined from economic analysis to avoid confusion and inconsistency of outcome to promote competition and the economic objectives. However, invariably social goals can be taken into consideration if they can be translated into economic efficiency gains or if they are found to produce pro-competitive

\footnotetext{
64 ASEAN, Regional Guidelines on Competition Policy, Para. 2.2.1 (2010).

65 OECD and The World Bank, supra note 15, 5.
} 
effect (i.e. where they cure market failures by enhancing information, by rectifying imbalances of power or by internalising externalities). For example, in the EU, non-economic goals of competition law can be pursued if they are translated into efficiency and technological benefits as contained in Art 101(3) of TFEU.

A country may also exclude or exempt a list of specific activities or agreements based on public interest or social objectives. This may include activities that are based on the principle of solidarity, service of general economic interest, collective bargaining, etc. However, this must follow the principle of proportionality to prevent any abuse of discretionary power in excluding certain activities.'Proportionality' means any conduct that restricts competition should not go beyond what is necessary to ensure the effective fulfilment of the objectives. The EC principle of proportionality requires that measures adopted by community institutions do not exceed the limits of what is appropriate and necessary to achieve the objectives legitimately pursued by the legislation in question; when there is a choice between several appropriate measures, recourse must be had to the least onerous, and the disadvantages caused must not be disproportionate to the aims pursued. ${ }^{66}$ The adoption of a block exemption regime is highly recommended. It provides a more transparent way to release certain activities from the ambit of competition law. Block exemption provides an opportunity for discussion before any agreement or activities are excluded for a certain period of time.

At the ASEAN level, it is possible to lay down identifiable social policy or social goals that should be allowed to be pursued through competition law. Though it may not be binding on Member States, it can serve as guidance on how to accommodate social goals through competition law enforcement, thus providing more certainty and transparency. Member States should be obliged to provide reason for any decision allowing social goals to be taken into consideration in their competition law enforcement.

66 Case C-331/88, The Queen v Minister of Agriculture, Fisheries and Food and Secretary of State for Health, ex parte: Fedesa and Others [1990] ECR I-04023, para 13. See also European Commission, Communications from the Commission -- Service of General Interest in Europe (2001) OJ C 17/4, Para 23. 


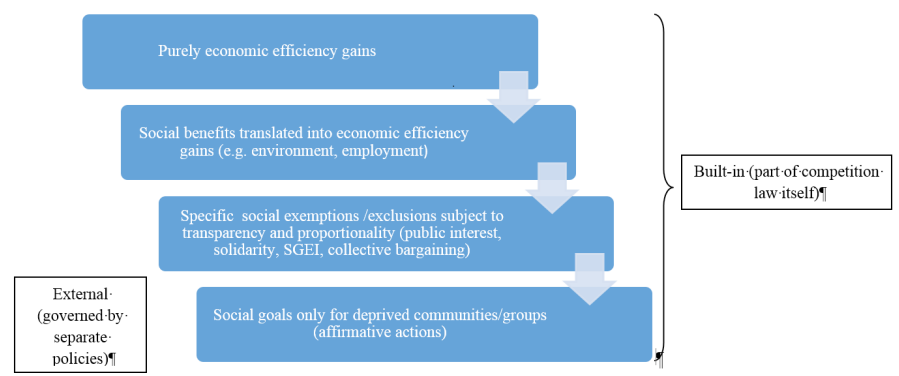

Figure 1: Proposed Model on the Social Boundaries of Competition Law

There are certain social policy goals that must be championed as they are necessary for deprived communities or groups. The attainment of these policy goals may collide with economic efficiency goals and the interests of some persistently deprived individuals can be aggregated so that "the law" may take into account the specific needs of rural communities, disabled people, poor farmers and fishermen, and indigenous people. However, such law is more appropriate to be represented by the regulatory framework promoting socio-economic development, not the law regulating competition in the market. Moreover, the application of such socio-economic regulatory framework must be an exception to the general rule. Too broad an interpretation of "persistent deprivation" will compromise the centrality of protecting the competitive process in competition law.

The Figure 1 illustrates the model that informs the discussions on possible common social denominators within competition regulation in ASEAN.

\section{CONCLUSION}

Competition law has a multiplicity of goals, both economic and non-economic, and the interplays between these different goals may generate diverse competition rules between AMSs which are evident in ASEAN. There are different approaches taken by different AMSs to regulating competition especially Indonesia which practices multiple objectives of competition law while Singapore and Malaysia focuses on protection of the process of competition. The practice by 
Indonesia gives room for social considerations to be included within its competition regulatory framework. However, this may not be the case in other AMSs. Therefore there is a need to look into a common approach to the law in ASEAN. This paper finds that economic efficiency must still take priority over other goals, including social goals. Flexibility however should be given to AMSs to create "safety valves" for the stakeholders based on legitimate social grounds depending on the prevalent political, legal, economic and social environment in the respective AMS. Certain margins of appreciation must be accorded to the competition authorities of the AMSs in making "social interventions" in competition decision making. However the AMSs must utilise the flexibility in good faith so that inconsistencies in practice can be reduced. Should the inconsistencies be too hard to be avoided they may be moderated through a coordination mechanism that can be established at the ASEAN level. 